\title{
Early Changes in Hippocampal Eph Receptors Precede the Onset of Memory Decline in Mouse Models of Alzheimer's Disease
}

\author{
Ana María Simón ${ }^{\mathrm{a}, \mathrm{c}, 1}$, Rakel López de Maturana ${ }^{\mathrm{a}, \mathrm{c}, 1}$, Ana Ricobaraza $^{\mathrm{a}, \mathrm{c}}$, Luis Escribano $^{\mathrm{a}, \mathrm{c}}$, \\ Lucio Schiapparellia,c, Mar Cuadrado-Tejedor ${ }^{\mathrm{a}, \mathrm{c}}$, Alberto Pérez-Mediavilla ${ }^{\mathrm{a}, \mathrm{c}}$, Jesús Avila ${ }^{\mathrm{b}, \mathrm{c}}$, \\ Joaquín Del Río ${ }^{\mathrm{a}, \mathrm{c}, *}$ and Diana Frechilla ${ }^{\mathrm{a}, \mathrm{c}}$ \\ ${ }^{a}$ Division of Neurosciences, CIMA, University of Navarra, Pamplona, Spain \\ ${ }^{\mathrm{b}}$ Center for Molecular Biology "Severo Ochoa", CSIC/UAM, Cantoblanco, Madrid, Spain \\ ${ }^{\mathrm{c}}$ CIBERNED, Spain
}

Accepted 22 January 2009

\begin{abstract}
Synapse loss occurs early in Alzheimer's disease (AD) and is considered the best pathological correlate of cognitive decline. Ephrins and Eph receptors are involved in regulation of excitatory neurotransmission and play a role in cytoskeleton remodeling. We asked whether alterations in Eph receptors could underlie cognitive impairment in an AD mouse model overexpressing human amyloid- $\beta$ protein precursor $(\mathrm{hA} \beta \mathrm{PP})$ with familial mutations $\left(\mathrm{hA} \beta \mathrm{PP}_{\text {swe-ind }}\right.$ mice). We found that EphA4 and EphB2 receptors were reduced in the hippocampus before the development of impaired object recognition and spatial memory. Similar results were obtained in another line of transgenic A $\beta$ PP mice, Tg2576. A reduction in Eph receptor levels was also found in postmortem hippocampal tissue from patients with incipient AD. At the time of onset of memory decline in $\mathrm{hA} \beta \mathrm{PP}_{\text {swe-ind }}$ mice, no change in surface expression of AMPA or NMDA receptor subunits was apparent, but we found changes in Eph-receptor downstream signaling, in particular a decrease in membrane-associated phospho-cofilin levels that may cause cytoskeletal changes and disrupted synaptic activity. Consistent with this finding, Eph receptor activation in cell culture increased phospho-cofilin levels. The results suggest that alterations in Eph receptors may play a role in synaptic dysfunction in the hippocampus leading to cognitive impairment in a model of AD.
\end{abstract}

Keywords: Alzheimer's disease, cofilin, ephrin, Eph receptor, glutamate receptor, LIM-kinase, memory, p21-activated kinase

\section{INTRODUCTION}

Alzheimer's disease (AD) is a progressive neurodegenerative disorder characterized by two histopathological hallmarks, the amyloid plaques, mainly com-

\footnotetext{
${ }^{1}$ These authors contributed equally to this work.

${ }^{*}$ Corresponding author: Dr. Joaquín Del Río, Division of Neurosciences, CIMA, University of Navarra, Av. Pio XII 55, 31008 Pamplona, Spain. Tel./Fax: +34 948 194700/15, E-mail: jdelrio@unav. es.
}

posed of the amyloid- $\beta(\mathrm{A} \beta)$ peptide, and the neurofibrillary tangles, comprised of hyperphosphorylated protein tau [1]. Yet, it is now well documented that the best neuropathological correlate of cognitive decline in $\mathrm{AD}$ patients is a severe synapse loss in the hippocampus and other brain regions. In addition, the remaining dendrites of affected neurons show a dystrophic pattern [2]. Accordingly, AD is now considered as a synaptopathy.

Several findings in brains of AD patients and transgenic animal models suggest that synaptic function is compromised prior to physical degeneration of the 
synapses $[3,4]$. The high plasticity of synapses is essential for numerous events associated with cognition. Of particular relevance for memory consolidation is the increase in strength of excitatory inputs to the postsynaptic neuron and the remodeling of cytoskeleton (e.g., [5]). NMDA and AMPA glutamate receptor subtypes are the primary mediators of excitatory synaptic transmission in the hippocampus. Both of them are essential for LTP induction and maintenance respectively and are required for spatial learning and memory [6]. Changes in the cytoskeleton also have a crucial role in synaptic plasticity, and synaptic strength is correlated with the size of dendritic spines and their capacity of remodeling [7].

Among signals that regulate excitatory synaptic strength and cytoskeleton architecture, ephrins and their receptors play a crucial role [8]. Ephrins and Eph receptors are cell-surface proteins implicated in developmental events such as tissue patterning, angiogenesis, and axon guidance $[9,10]$, and in regulation of synapse function and plasticity in the adult brain, particularly in the hippocampus [11,12]. Eph receptors form the largest family of receptor tyrosine-kinases and 14 different members have been identified at present in mammals (EphA1-8 and EphA10, EphB1-4 and EphB6) [13]. Eph receptors maintain and stabilize synaptic structure through activation of small $\mathrm{G}$ proteins, RhoA, Rac, and Cdc42 among others, and downstream effectors such as cofilin [14,15], and also regulate glutamatergic neurotransmission through modulation of NMDA and AMPA receptor function [16]. The critical role of Eph receptor subtypes in synaptic plasticity has been demonstrated in numerous studies [1719]. EphA4 and EphB2 are the two Eph receptors most intensively studied in the adult brain, where they have been detected in many regions, especially in the neocortex and hippocampus [20,21]. The multiple pathways involved in the regulation of synaptic function after Eph receptor activation remain to be fully elucidated.

In transgenic mice overexpressing human amyloid$\beta$ protein precursor $(\mathrm{hA} \beta \mathrm{PP})$, levels of a $56-\mathrm{kDa}$ oligomeric soluble species of $\mathrm{A} \beta$, but not of insoluble $\mathrm{A} \beta$, correlate with memory impairment [22], perhaps through an interaction with glutamate receptors [23]. Indeed, some reports have shown alterations in AMPA and NMDA receptors in postsynaptic hippocampal membranes of brains from both AD patients [24] and cultured neurons of $\mathrm{A} \beta \mathrm{PP}$ transgenic mice $[25,26]$. Because of the critical role of Eph receptors in synaptic plasticity, we explored the possibility that Eph receptor alterations could be correlated with cognitive deficits in these mice so we analyzed the time-course of the expression of EphA4 and EphB2 receptors, which present an overlapping distribution in the hippocampus [20], as well as AMPA and NMDA receptor subunit levels, looking for a correlation with the progression of cognitive impairment. We also sought other related molecular changes downstream of ephrin-Eph receptor signaling, such as p21-activated kinase (PAK), LIM-kinase (LIMK), and in particular alterations in the activity of cofilin, a protein of the cofilin/actin depolymerization factor family that binds and depolymerizes actin filaments [27] and is consequently implicated in the plasticity of dendritic spines. Many recent studies [28-30] have highlighted the role of altered cofilin activity as an important factor contributing to neuronal degeneration in $\mathrm{AD}$.

\section{MATERIALS AND METHODS}

Mice

Transgenic $\mathrm{hA} \beta \mathrm{PP}_{\text {swe-ind mice overexpressing }}$ $\mathrm{hA} \beta \mathrm{PP}$ with the Swedish (K670N/M671L) and Indiana (V717F) familial AD mutations under control of the PDGF promoter were used in this study (J20 line) [31]. The mice were on an inbred C57BL/6J genetic background. Some experiments were also performed with $\operatorname{Tg} 2576$ mice (Taconic, NY, USA) that overexpress hA $\beta$ PP with the double Swedish mutation [32]. Animals were housed four-five per cage with free access to food and water and maintained in a temperature-controlled environment on a $12 \mathrm{~h}$ light/dark cycle. All procedures were carried out in accordance with European and Spanish regulations (86/609/CEE; RD1201/2005). This study was approved by the Ethical Committee of the University of Navarra (no. 018/05).

\section{Postmortem human brain tissue}

Frozen postmortem human brain tissue was obtained from the Neurological Tissue Bank of Navarra Hospital. Hippocampal sections from three AD cases and three age-matched non-demented controls were analyzed. All cases had been neuropathologically confirmed, using conventional histopathological techniques, and diagnosis performed using the CERAD criteria. Neuropathological staging of neurofibrillary changes (I-VI) was performed according to Braak and Braak [33]. The three AD cases were assigned to Braak stage II/III (CERAD stage A). 


\section{Cell cultures}

Primary neuronal cultures were prepared from hippocampi of embryonic day 16 (E16) $\mathrm{hA} \beta \mathrm{PP}_{\text {swe-ind }}$ mice and non-transgenic littermates. One pup corresponded to one set of cultures, and genotyping was performed using the cerebellum. After mechanical dissociation, cells were cultured on poly-L-lysine coated plates maintained in Neurobasal medium (Invitrogen) containing 2\% B27 supplement (Invitrogen), $1 \%$ GlutaMAX $^{\mathrm{TM}} \mathrm{I}$ (Invitrogen), and $1 \%$ penicillin (10,000 units/ml)/streptomycin $(10,000 \mu \mathrm{g} / \mathrm{ml})$ (Invitrogen) at $37^{\circ} \mathrm{C}$ in a humidified $5 \% \mathrm{CO}_{2}$ atmosphere. After 20 days in vitro (DIV), whole-cell lysates were prepared as below described.

Human neuroblastoma SH-SY5Y cells were grown in Dulbecco's modified Eagle medium (DMEM) (Sigma) supplemented with $10 \%$ fetal bovine serum (Sigma), $1 \%$ GlutaMAX $^{\mathrm{TM}}$ I (Invitrogen), and $1 \%$ penicillin $(10,000$ units/ml)/streptomycin $(10,000 \mu \mathrm{g} / \mathrm{ml})$ (Invitrogen) at $37^{\circ} \mathrm{C}$ in a humidified $5 \% \mathrm{CO}_{2}$ atmosphere. Serum-starved SH-SY5Y cells were treated with $4 \mu \mathrm{g} / \mathrm{ml}$ preclustered human ephrinB3/Fc (R\&D Systems) at $37^{\circ} \mathrm{C}$ for $15 \mathrm{~min}$. Preclustering of the ephrin ligand/Fc chimera was achieved by incubation with anti-human $\mathrm{Fc}$ antibodies (Jackson ImmunoResearch Labs) at a $2: 1$ ratio $(\mathrm{w} / \mathrm{w})$ for $1 \mathrm{~h}$ at $4{ }^{\circ} \mathrm{C}$ (e.g., [34]). Control cells were treated with anti-Fc antibodies only. After cell stimulation, whole-cell lysates were prepared.

\section{Production of protein extracts}

Total tissue lysates from mouse or human brain were obtained by homogenizing the hippocampus in ice-cold RIPA buffer (50 mM Tris- $\mathrm{HCl} \mathrm{pH} 7.4,0.25 \%$ sodium deoxycholate (DOC), 1\% Nonidet P-40, $150 \mathrm{mM}$ $\mathrm{NaCl}, 1 \mathrm{mM}$ EDTA, $1 \mathrm{mM}$ PMSF, $1 \mu \mathrm{g} / \mathrm{ml}$ leupeptin, $1 \mu \mathrm{g} / \mathrm{ml}$ aprotinin, $1 \mathrm{mM} \mathrm{Na}{ }_{3} \mathrm{VO}_{4}, 1 \mathrm{mM} \mathrm{NaF}$ ), centrifuged at $14,000 \mathrm{~g}, 4^{\circ} \mathrm{C}$ for $20 \mathrm{~min}$ and the supernatant was aliquoted and frozen at $-80^{\circ} \mathrm{C}$. The same method was used for obtaining whole-cell lysates. To obtain the membrane-enriched protein fraction (P2 membrane proteins), a previously described method [35] was used. The hippocampus was homogenized in ice-cold TrisEDTA buffer (10 mM Tris-HCl and $5 \mathrm{mM}$ EDTA, $\mathrm{pH}$ 7.4), containing $320 \mathrm{mM}$ sucrose and the protease and phosphatase inhibitors previously described. The tissue homogenate was centrifuged at $700 \mathrm{~g}$ for $10 \mathrm{~min}$. The supernatant was centrifuged again at 37,000 $\mathrm{g}$ for $40 \mathrm{~min}$ at $4^{\circ} \mathrm{C}$. The pellet $(\mathrm{P} 2)$ was resuspended in
$10 \mathrm{mM}$ Tris-HCl buffer ( $\mathrm{pH} 7.4$ ), containing the enzyme inhibitor mixture described above. In both cases, protein concentration was determined (Bio-Rad Bradford assay) and aliquots were stored at $-80^{\circ} \mathrm{C}$ until used. For Western blot analysis, aliquots of the P2 membrane fraction were solubilized in non-denaturing conditions by adding 0.1 vol of $10 \%$ DOC in $500 \mathrm{mM}$ Tris- $\mathrm{HCl}$ buffer ( $\mathrm{pH} 9)$. The samples were incubated for $30 \mathrm{~min}$ at $36^{\circ} \mathrm{C}$ and diluted by adding 0.1 volume of $500 \mathrm{mM}$ Tris- $\mathrm{HCl}(\mathrm{pH} 9) / 1 \%$ Triton $\mathrm{X}-100$. After a centrifugation at $37,000 \mathrm{~g}$ for $10 \mathrm{~min}$ at $4{ }^{\circ} \mathrm{C}$, the supernatant was frozen at $-80^{\circ} \mathrm{C}$.

\section{Western blotting}

Protein samples were mixed with an equal volume of 2x Laemmli sample buffer, resolved onto SDS-polyacrylamide gels and transferred to nitrocellulose membrane (Hybond ECL, Amersham Biosciences) using a Trans-Blot ${ }^{\circledR}$ SD semidry system (Bio-Rad) for $30 \mathrm{~min}$ at $12 \mathrm{~V}$. The membranes were blocked with $5 \%$ milk, $0.05 \%$ Tween-20 in PBS or TBS followed by overnight incubation with the following primary antibodies: goat polyclonal antiEphA4 (0.2 $\mu \mathrm{g} / \mathrm{ml}, \mathrm{R} \& \mathrm{D}$ Systems), goat polyclonal anti-EphB2 $(0.2 \mu \mathrm{g} / \mathrm{ml}, \mathrm{R} \& \mathrm{D}$ Systems $)$, rabbit polyclonal anti-PAK1/2/3 (1:2000, Cell Signaling), rabbit polyclonal anti-phospho-PAK1/2/3 (Ser141) (1:2000, Invitrogen), rabbit polyclonal anti-LIMK1 (1:1000, Santa Cruz), rabbit polyclonal anti-phospho-LIMK1 (Thr508)/LIMK2 (Thr505) (1:1000, Cell Signaling), rabbit polyclonal anti-cofilin (1:1000, Chemicon), rabbit polyclonal anti-phospho-cofilin (Ser3) (1:1000, Cell Signaling), rabbit polyclonal anti-GluR1 $(0.2 \mu \mathrm{g} / \mathrm{ml}$, Chemicon), rabbit polyclonal anti-GluR2/3 $(0.1 \mu \mathrm{g} / \mathrm{ml}$, Chemicon), rabbit polyclonal anti-NR1 (1:1000, Upstate), rabbit polyclonal anti-NR2A (1:1000, Upstate), rabbit polyclonal anti-NR2B (1:1000, Upstate), and mouse monoclonal anti- $\beta$-actin (1:100000, Sigma), in the corresponding buffer. Following two washes in PBS/Tween-20 or TBS/Tween20 and one PBS or TBS alone, immunolabeled protein bands were detected by using HRP-conjugated anti-rabbit or antimouse antibody (Dako; dilution 1:1500) following an enhanced chemiluminiscence system (ECL Amersham Biosciences), and autoradiographic exposure to Hyperfilm ${ }^{\mathrm{TM}}$ ECL (Amersham Biosciences). The quantification of signals was performed using Scion Image software (Scion Corporation). 


\section{Behavioral procedures}

Object recognition test. The apparatus consisted of a dark open box $(50 \times 35 \times 50 \mathrm{~cm}$ high $)$, illuminated by a $60 \mathrm{~W}$ lamp suspended $120 \mathrm{~cm}$ above the box. The different objects consisted in general in red rectangular prisms $(2 \times 2 \times 8 \mathrm{~cm}$ high $)$ and white pyramids $(5 \times$ $5 \times 5 \mathrm{~cm}$ high). These objects could not be displaced by the mice. In the week preceding testing, the animals were handled daily and adapted to the room in which the behavioral procedures were performed. The object recognition test was performed as described elsewhere $[36,37]$ with minor modifications. One h before testing, the mice were allowed to explore the apparatus without objects for $5 \mathrm{~min}$. After habituation, two familiarization sessions were given (T1 and T2 $10 \mathrm{~min}$ apart), in which the animals were left to explore for 10 min two identical objects (red prisms) that were placed in opposite sides of the apparatus $10 \mathrm{~cm}$ from the side wall. The choice trial (T3), in which memory retention was tested, was given $24 \mathrm{~h}$ after $\mathrm{T} 2$. In this session, two objects were presented, one of the prisms used in familiarization session (T1 and T2) and other different in shape and color; therefore the mice were re-exposed to a familiar $(\mathrm{F})$ and a novel object $(\mathrm{N})$. Exploration was defined as directing the nose to an object at a distance $\leqslant 2 \mathrm{~cm}$ and/or touching the object with the nose.

To avoid the presence of olfactory trails, the apparatus and the objects were thoroughly cleaned after each trial. The time spent by the animals in exploring each object was recorded manually by using a stopwatch. The reaction to a novel object during T3 was measured by calculating the discrimination index (DI): time spent exploring the novel object over total exploration time. Consequently, a ratio of 0.5 reflects equal exploration of the familiar and the novel object, indicating no learning retention

Morris water maze. Groups of transgenic hA $\beta \mathrm{PP}$ swe-ind mice and non transgenic littermates $(n=12)$, underwent spatial reference learning and memory in the Morris water maze (MWM) test, a hippocampusdependent learning task. The maze was a circular tank (diameter $1.45 \mathrm{~m}$ ) filled with water at $20^{\circ} \mathrm{C}$. Mice underwent visible-platform training for three consecutive days ( 8 trials/day), and were allowed to swim to a raised platform located above the water. Hidden-platform training was conducted over 9 consecutive days (4 trials/day). Mice had $60 \mathrm{~s}$ to find a hidden platform submerged $1 \mathrm{~cm}$ beneath the surface of the water and invisible to the mice while swimming. Several large visual cues were placed in the room to guide the mice to the hidden platform. Mice failing to reach the platform were guided onto it. All the animals were allowed to rest on the platform for $20 \mathrm{~s}$ and then removed from the platform and returned to their home cage. At the beginning of 4th, 7th, and 9th day of the task, a probe trial in which the platform was removed from the pool was conducted, and the mice were permitted to search the platform for $60 \mathrm{~s}$. All trials were monitored by a camera using an HVS water maze program for analyses of escape latencies and percent time spent in each quadrant of the pool during probe trials (analysis program Ethovision, Wageningen, The Netherlands). Mice that were unable to reach the visible-platform or mice exhibiting abnormal swimming patterns or persistent floating were excluded from data analyses.

\section{Statistical analysis}

Compiled data were expressed as means \pm SEM. Statistical analysis was assessed with SPSS version 11.5 (SPSS. Inc. Chicago, IL) using the parametric Student's t-test or the non-parametric Mann-Whitney U-test to compare two independent groups. A level of significance was set at $P<0.05$ for comparative measurement throughout the study.

\section{RESULTS}

EphA4 and EphB2 receptor protein in transgenic A $\beta P P$ mice

We analyzed EphA4 and EphB2 receptor protein levels in hipppocampal lysates by immunoblotting. A reduction of EphA4 levels was apparent in whole-cell

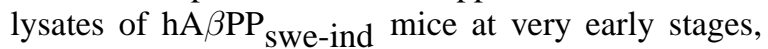
$\sim 40 \%$ at 2 months and $\sim 20 \%$ at 4 months, and also in 8-month-old animals (Fig. 1A). EphB2 receptor protein levels were markedly reduced, by $\sim 40 \%$, in tissue lysates of 2-month-old hA $\beta \mathrm{PP}_{\text {swe-ind }}$ mice (Fig. 1B). In 4- and 8-month-old hA $\beta \mathrm{PP}_{\text {swe-ind }}$ mice, no significant change was found in EphB2 receptor protein levels in hippocampal extracts (Fig. 1B).

It appeared of interest to extend these experiments to another line of transgenic $\mathrm{A} \beta \mathrm{PP}$ mice. In 5-monthold $\mathrm{Tg} 2576$ mice, EphA4 and EphB2 receptor protein levels were reduced by $\sim 38 \%$ and $25 \%$ respectively (Fig. 2). Spatial memory was not impaired in Tg2576 mice until 4-5 months later (not shown).

A reduction of EphA4 and EphB2 receptor protein levels was also found in primary hippocampal cultures obtained from embryonic (E16) hA $\beta \mathrm{PP}_{\text {swe-ind }}$ transgenic mice maintained 20 days in culture (Fig. 3). 


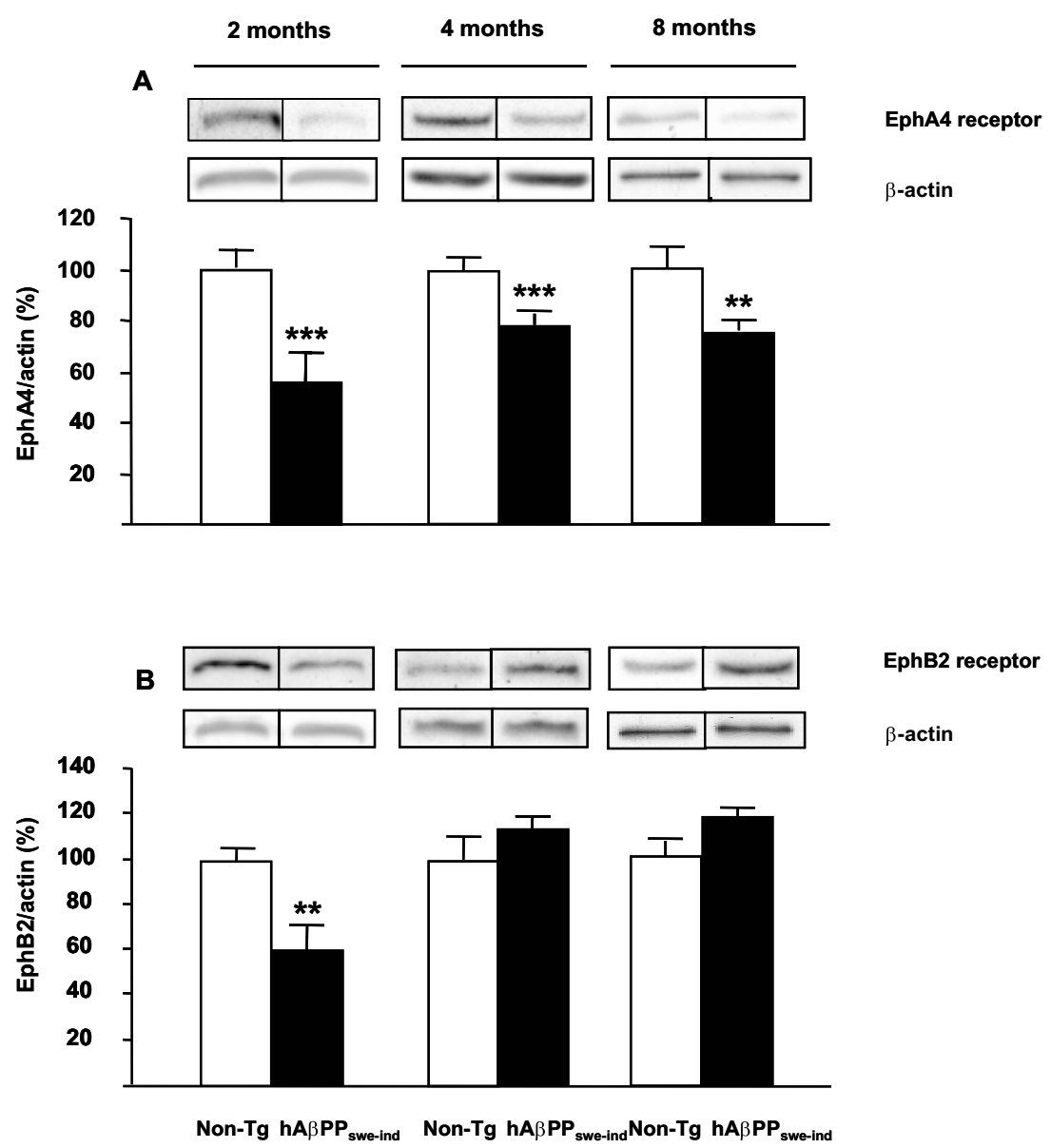

Fig. 1. EphA4 (A) and EphB2 (B) receptor protein levels quantified by Western blot in tissue lysates from the hippocampus of non-transgenic

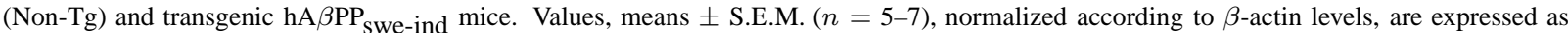
percentage of optical density (OD) of the corresponding Non-Tg mice. All experiments were performed in triplicate. ${ }^{* *} \mathrm{P}<0.01 ; * * * \mathrm{P}<0.001$ $v s$. non-transgenic mice (Student's t test).

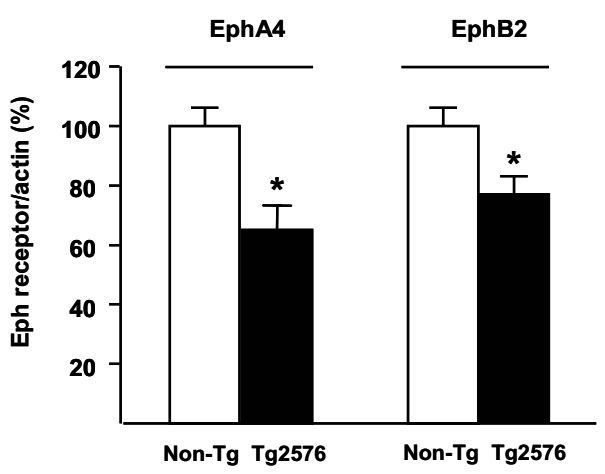

Fig. 2. EphA4 and EphB2 receptor protein levels quantified by Western blot in tissue lysates from the hippocampus of 5-month-old non-transgenic (Non-Tg) and transgenic Tg2576 mice. Values, means \pm S.E.M. $(n=5)$, normalized according to $\beta$-actin levels, are expressed as percentage of optical density (OD) of the corresponding Non-Tg mice. All experiments were performed in triplicate. ${ }^{*} \mathrm{P}<0.05$ vs. non-transgenic mice (Student's t test). 

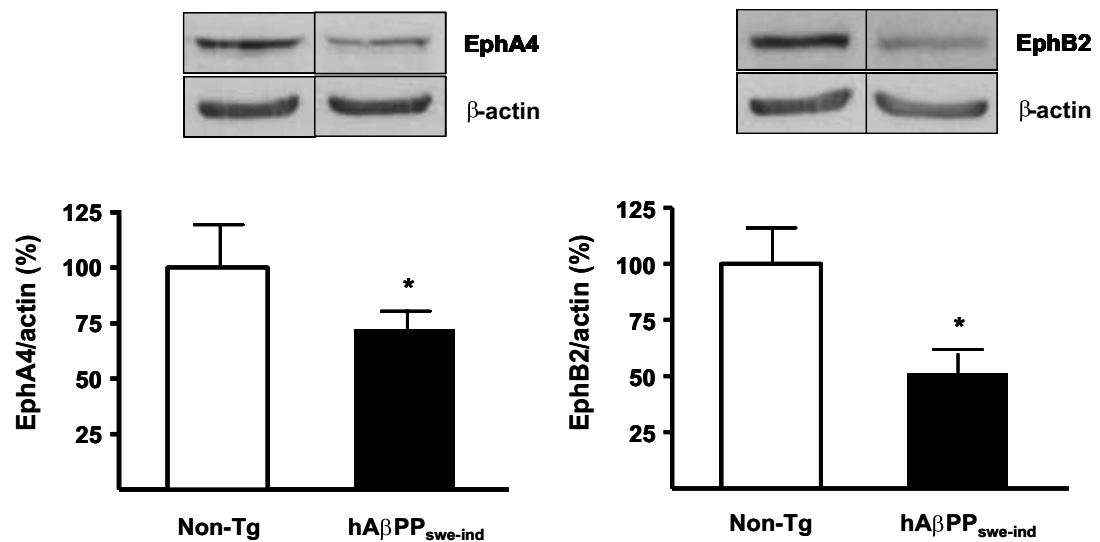

Fig. 3. EphA4 and EphB2 receptor protein levels quantified by Western blot in cell homogenates from primary hippocampal cultures at 20

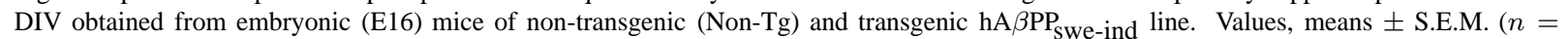
5), are normalized according to $\beta$-actin levels and expressed as percentage of optical density (OD) of the corresponding Non-Tg cultures. All experiments were performed in triplicate. ${ }^{*} \mathrm{P}<0.05 v$ s. non-transgenic cultures (Student's t test).
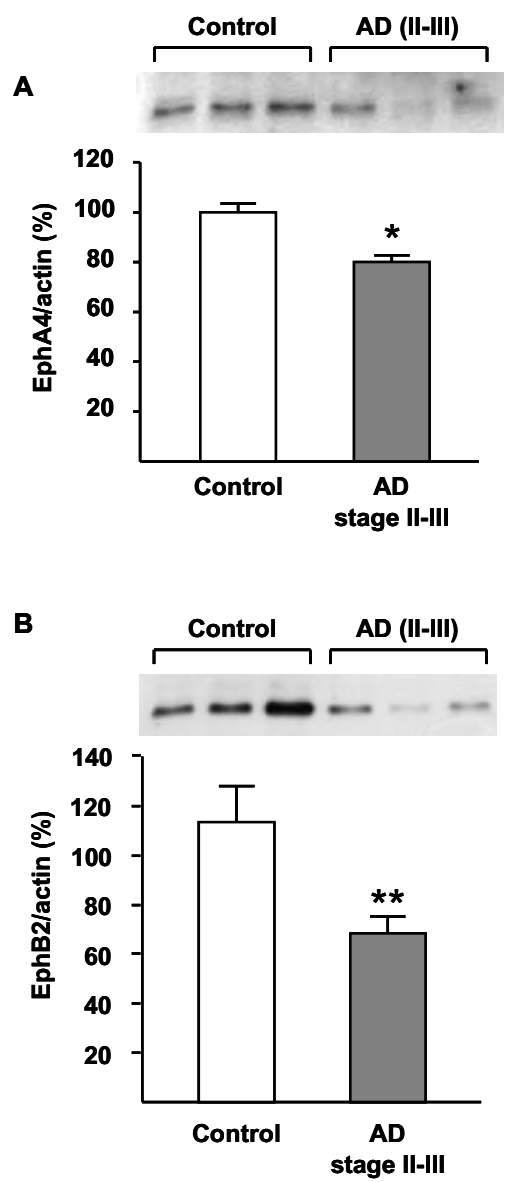

Fig. 4. EphA4 (A) and EphB2 (B) receptor protein levels quantified by Western blot in tissue lysates from the hippocampus of Alzheimer's disease (AD) patients with incipient disease (Braak stage II-III, $n=3$ ), and the corresponding controls $(n=3)$. Values, means \pm S.E.M., normalized according to $\beta$-actin levels, are expressed as percentage of optical density (OD). All experiments were performed in triplicate $* \mathrm{P}<$ $0.05 ; * * \mathrm{P}<0.01 v s$. controls (Mann Whitney U-test). 

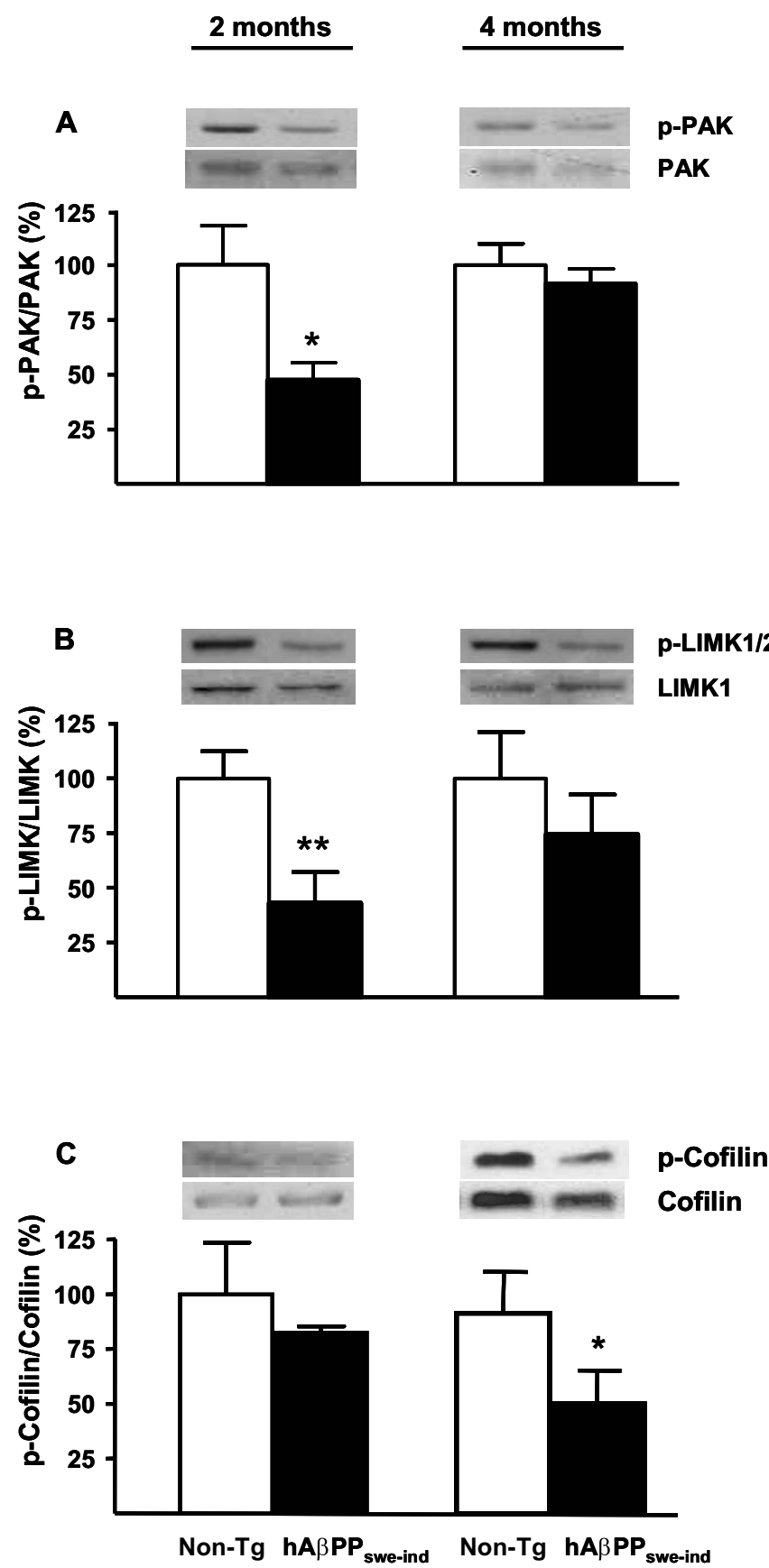

Fig. 5. p-PAK/PAK (A), p-LIMK/LIMK (B) and p-Cofilin/Cofilin (C) ratios in membrane preparations from the hippocampus of non-transgenic (Non-Tg) and transgenic hA $\beta \mathrm{PP}_{\text {swe-ind }}$ mice at 2 and 4 months of age. Values, means \pm S.E.M. $(n=6)$, are expressed as percentage of optical density (OD) of Non-Tg mice. All experiments were performed in triplicate. ${ }^{*} \mathrm{P}<0.05 ; * * \mathrm{P}<0.01$ vs. non-transgenic mice (Student's t test).

\section{EphA4 and EphB2 receptors in postmortem brain} tissue from $A D$ patients

Given that EphA4 and EphB2 receptor levels were reduced in transgenic hA $\beta \mathrm{PP}$ mice, we also measured receptor levels in hippocampal tissue from AD patients. This study included the analysis of hippocampus from patients with an incipient AD (Braak stages II/III) and from the corresponding age-matched controls. Interestingly, in keeping with the early changes observed in 
transgenic A $\beta$ PP mice, we found a significant decrease in protein levels of both Eph receptors in the hippocampus from patients at an incipient stage of the disease ( $\sim 20 \%$ in EphA4 and $~ 35 \%$ in EphB2 receptor protein levels) (Fig. 4).

\section{PAK, LIM-kinase and cofilin levels and activity in $h A \beta P P_{\text {swe-ind }}$ mice}

As we found lower Eph receptor levels in young $\mathrm{hA} \beta \mathrm{PP}_{\text {swe-ind }}$ mice, we hypothesized that signaling downstream these receptors could be downregulated. We then determined the levels and activation state of three molecules regulated by Eph signaling in hippocampal extracts from 2- and 4-month-old $\mathrm{hA} \beta \mathrm{PP}_{\text {swe-ind }}$ mice. Cofilin activity is regulated by kinases such as LIM-kinase $1 / 2$, which in turn is regulated by PAK $[38,39]$.

In membrane preparations from the hippocampus, both phospho-PAK and phospho-LIMK levels, the active forms of the enzymes, were reduced in 2 month- but not in 4 month-old mice (Fig. 5A,B). In the same preparations, we found that the decrease in phospho-cofilin levels, the inactive form, did not reach statistical significance in 2-month-old-mice. In 4 month-old mice, however, p-cofilin levels were markedly reduced (Fig. 5C). In all cases, the levels of the non-phosphorylated proteins were not significantly modified (Fig. 5). Studies performed on whole-cell lysates only revealed a slight non-significant tendency to increase in the p-PAK/PAK and $\mathrm{p}$-LIMK/LIMK ratios in 2 month-old mice, along with a lack of change in p-cofilin/cofilin levels (not shown).

\section{Effect of Eph receptor activation on phospho-cofilin levels in cell culture}

Because reduced phospho-cofilin levels might be attributed to the reduced expression of Eph receptors in transgenic $\mathrm{A} \beta \mathrm{PP}$ mice, we determined whether Eph receptor activation could increase phospho-cofilin levels in an in vitro assay. To activate Eph receptors, the ligand ephrinB3-Fc, that activates EphB(1-3) and EphA4 receptors was used. Exposure of a human neuroblastoma cell line to this ligand for 15 min produced a vast increase in phospho-cofilin levels (Fig. 6).

\section{AMPA and NMDA receptor subunits in $h A \beta P P_{\text {swe-ind }}$ mice}

Analysis by Western blot of AMPA receptor subunit GluR1 in solubilized membrane preparation revealed no modifications neither in 2 month- nor in 4 month-old

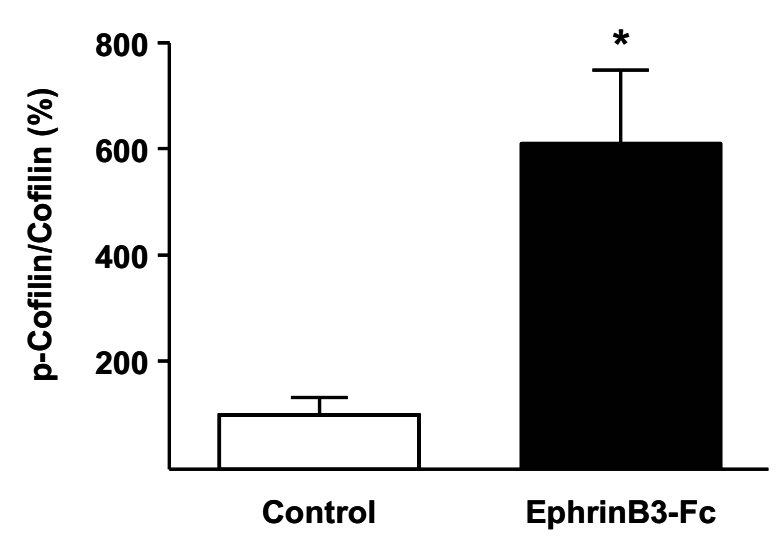

Fig. 6. Effect of ephrinB3-Fc on p-Cofilin/Cofilin ratio in lysates from cultured SH-SY5Y cells exposed to the the ligand $(4 \mu \mathrm{g} / \mathrm{ml})$ for $15 \mathrm{~min}$. Data are means \pm S.E.M. $(n=3-4)$. $* \mathrm{P}<0.05$ vs. $\mathrm{Fc}$ controls (Student's t test).

animals versus the non-transgenic mice. In 8 monthold mice, a significant decrease in GluR1 membrane levels, $\sim 40 \%(P<0.01)$, was found in the transgenic mice versus the non-transgenic controls (Fig. 7A). No changes in GluR2/3 membrane levels were detected at any time (Fig. 7B).

We also measured NMDA receptor NR1, NR2A and $\mathrm{NR} 2 \mathrm{~B}$ subunits in 8-month-old hA $\beta \mathrm{PP}_{\text {swe-ind }}$ transgenic mice. No change was observed in the levels of any subunit in membrane enriched fractions (Fig. 8).

\section{Behavioral studies}

Object recognition. Recognition memory was tested at early and late stages (2, 4, and 8 months) in $\mathrm{hA} \beta \mathrm{PP}_{\text {swe-ind }}$ transgenic mice. Impaired recognition memory was found in 4-month-old and older mice but not in younger animals (2 months). As shown in Fig. 9A, 4-month-old mice spent approximately the same time in the exploration of the new and the familiar object with a discrimination index, DI $=0.55 \pm$ 0.02 , significantly lower $(P<0.001)$ than that of nontransgenic mice, DI $=0.76 \pm 0.02$. No change in total exploration time was observed in these two groups (not shown)

Morris water maze. To assess spatial reference learning and memory function, groups of 2- and 4month old $\mathrm{hA} \beta \mathrm{PP}_{\text {swe-ind }}$ mice and the corresponding non-transgenic littermates ( $n=12$ per group) were tested in the MWM. No cognitive deficits were found in 2-month-old animals (not shown). In 4-monthold mice, no significant difference in escape latency among groups was found during the days of visible platform training (Fig. 9B). In the spatial refer- 


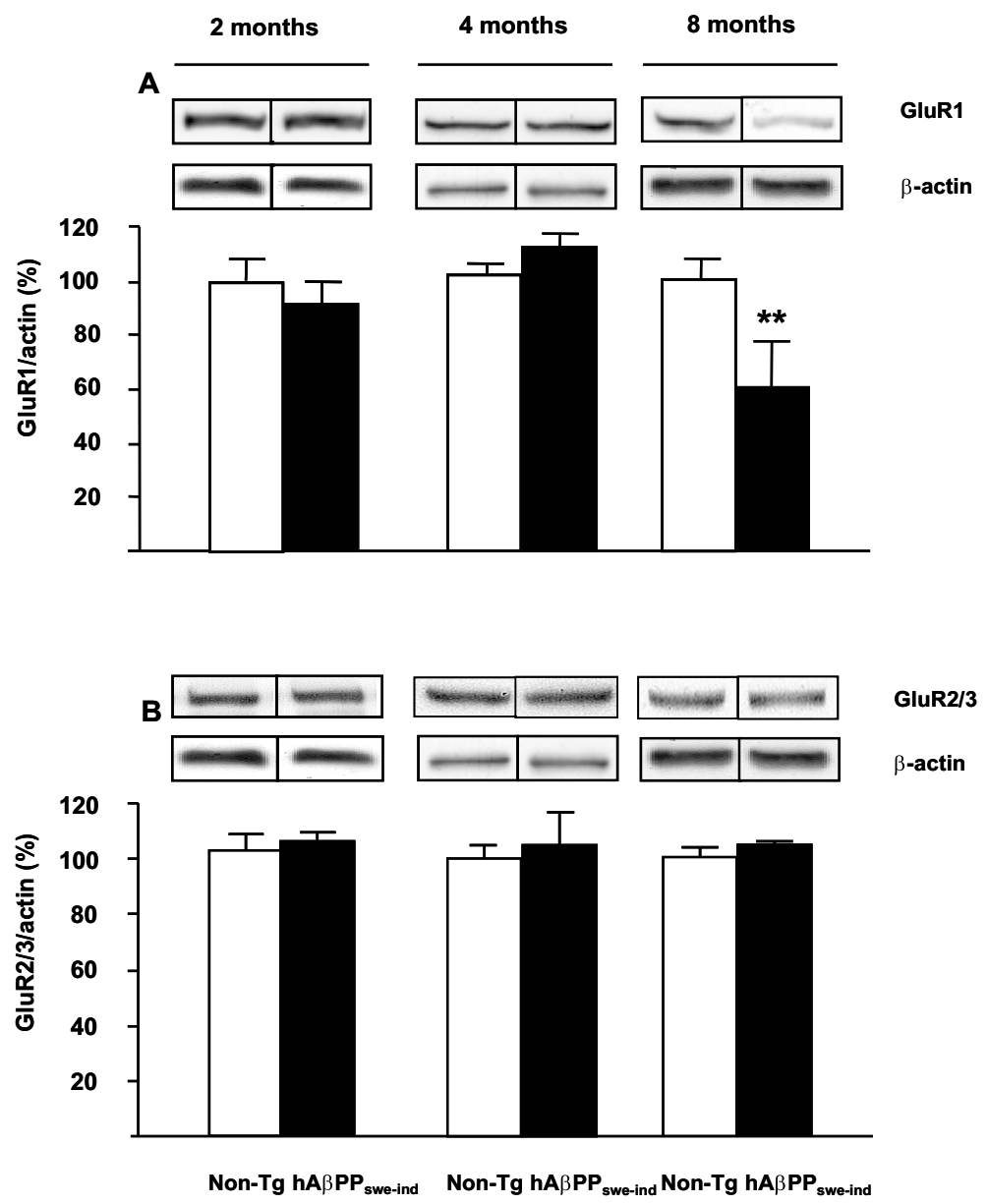

Fig. 7. AMPA receptor GluR1 (A) and GluR2/3 (B) subunit levels quantified by Western blot in membrane preparations from the hippocampus of non-transgenic (Non-Tg) and transgenic hA $\beta$ PP ${ }_{\text {swe-ind }}$ mice. Values, means \pm S.E.M. $(n=5-6)$, normalized according to $\beta$-actin levels, are expressed as percentage of optical density (OD) of the corresponding Non-Tg mice. All experiments were performed in triplicate $* * P<$ 0.01 vs. non-transgenic mice (Student's t test).

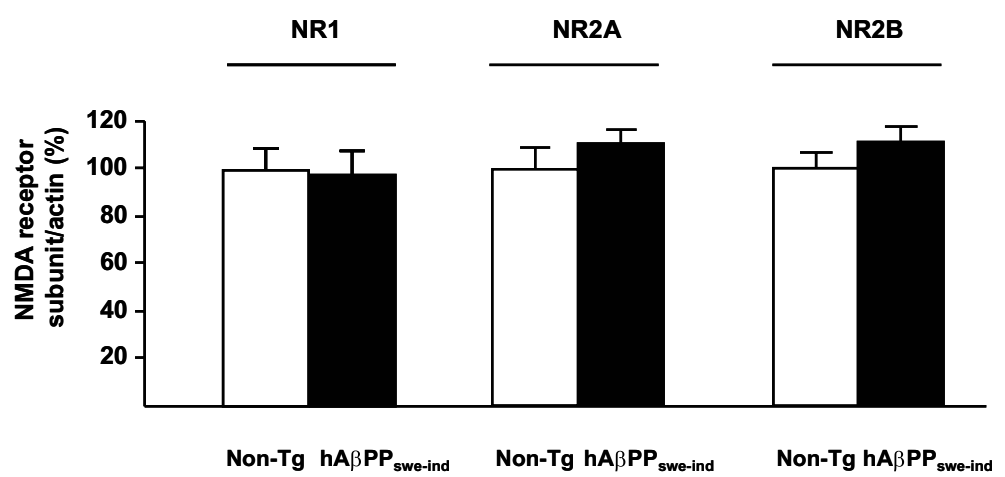

Fig. 8. NMDA receptor subunit levels quantified by Western blot in membrane preparations from the hippocampus of 8-month-old non-transgenic

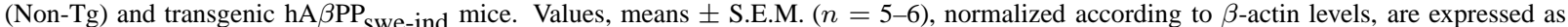
percentage of optical density (OD) of the corresponding Non-Tg mice. All experiments were performed in triplicate. Data are expressed as relative change $v s$. non-transgenic littermates processed in parallel. 


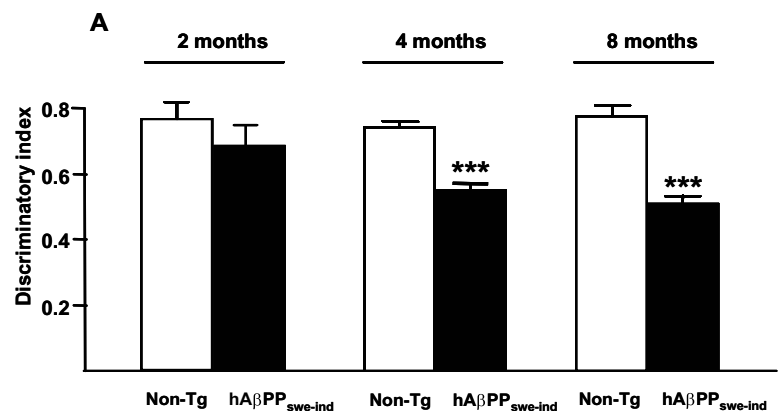

C

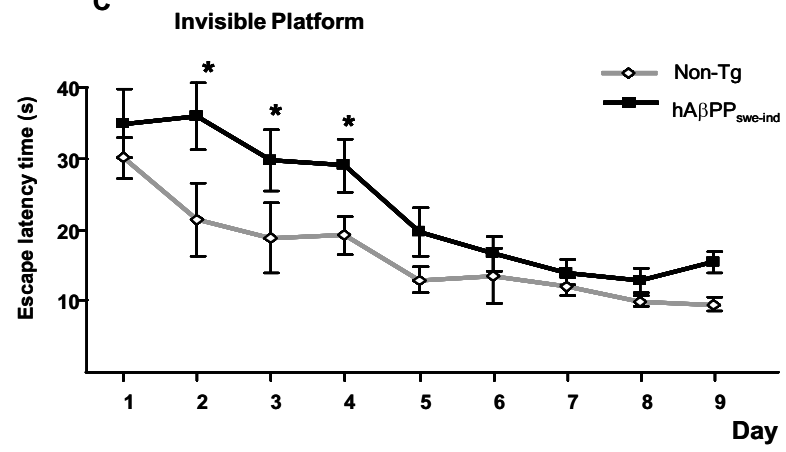

B

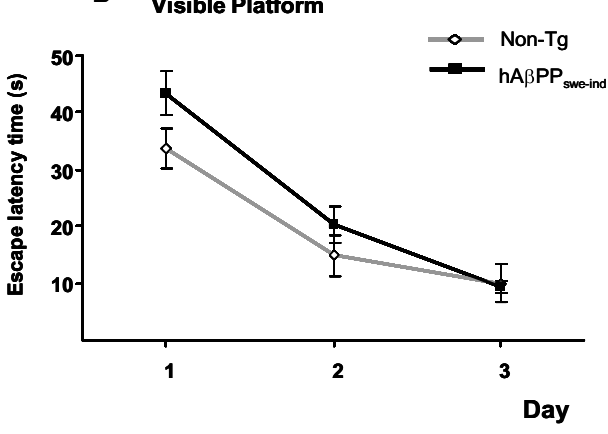

D Probe trial (15s)

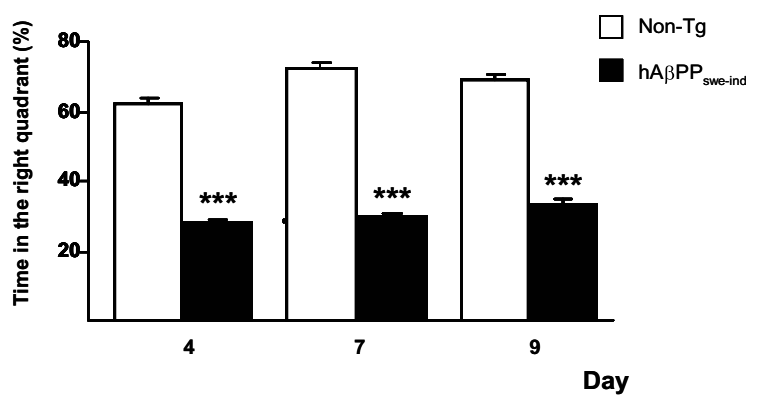

Fig. 9. Behavioral analyses in $\mathrm{hA} \beta \mathrm{PP}_{\text {swe-ind mice. (A) Impaired memory in } \mathrm{hA} \beta \mathrm{PP}}$ swe-ind transgenic mice in the object recognition test at different ages. The familiarization (T1) and choice (T2) sessions were spaced $24 \mathrm{~h}$ apart. Values are means \pm S.E.M. $(n=19-32$ in non-transgenic (Non-Tg) and $n=11-19$ in transgenic mice). $* * * P<0.001 v s$. Non-Tg mice (ANOVA followed by Sheffe t-test). (B) Escape latency in the visible platform training of 4-month-old hA $\beta \mathrm{PP}_{\text {swe-ind }}$ mice in the Morris water maze (MWM). (C) Escape latency in the invisible platform in the MWM ( ${ }^{\mathrm{P}}<0.05 v s$ Non-Tg, ANOVA followed by Student's t test). (D) Impaired memory in hA $\beta$ PP ${ }_{\text {Swe-ind }}{ }$ mice in the three $15 \mathrm{~s}$ probe trials $(* * * \mathrm{P}<0.001$, ANOVA followed by Student's $\mathrm{t}$ test).

ence training (invisible platform), a mixed multifactorial ANOVA analysis revealed a significant effect of transgenic status on the MWM test performance $(P<$ 0.05). $\mathrm{hA} \beta \mathrm{PP}_{\text {swe-ind mice showed escape latencies }}$ significantly longer than non-transgenic littermates on days 2-4 (Fig. 9C). It has been previously suggested that the sensitivity of MWM test can be increased by giving shorter probe trials [11], so we determined the performance of mice during the first $15 \mathrm{~s}$ of every probe trial. ANOVA revealed a significant effect of transgenic status in probe trials $(P<0.01) . \mathrm{hA} \beta \mathrm{PP}_{\text {swe-ind }}$ mice did not retain a clear bias for the platform location $24 \mathrm{~h}$ after the last training session on days 4, 7 and 9 and spent less time in the correct quadrant of the pool during every probe trial $(P<0.001)$ (Fig. 9D).

\section{DISCUSSION}

We found in $\mathrm{A} \beta \mathrm{PP}$ transgenic mice an early decrease in hippocampal EphA4 and EphB2 receptors that preceded an impaired object recognition and spatial mem- ory. No change in surface expression of AMPA or NMDA receptor subunits was found in hippocampal membrane preparations at the time of onset of memory decline. An increase in the membrane-associated activity of cofilin, a downstream effector of Eph receptors that could affect dendritic spine plasticity, was apparent in the hippocampus at this time point. The reduction found in p-PAK and p-LIMK levels may account for the increased cofilin activity. The observed changes suggest that early alterations in Eph receptor signaling may contribute to the synaptic dysfunction previous to synaptic loss in AD. Remarkably, reduced EphA4 and EphB2 levels were also found in postmortem hippocampal sections from patients at an incipient stage of AD.

Several biochemical signals regulate synaptic function and plasticity. Among them, ephrins and their receptors are good candidates because of their implication in synaptogenesis, synaptic plasticity, memory, regulation of excitatory neurotransmission, and reorganization of cytoskeleton in the adult brain $[9,12,40,41]$. This reorganization is necessary for the spine remod- 
eling associated with the stabilization of learning and memory [42]. Among the signals directly implicated in actin cytoskeleton dynamics, the actin-depolymerizing protein cofilin plays a crucial role [38]. It is known that ephrins and their receptors modulate cofilin activity through their action on small GTPases proteins of the Rho family, such as Rho A, Cdc42, and Rac, which in turn modulate the activity of two key proteins implicated in cofilin activation, PAK and LIMK [43]. When PAK and/or LIMK activity is reduced, cofilin is activated and binds to actin to promote its depolymerization.

EphA4 receptors are highly expressed in brain structures with marked synaptic plasticity such as the hippocampus [14], and electron microscopy studies have shown that these receptors are basically localized on dendritic spines of hippocampal pyramidal neurons as well as on axon terminals $[20,44]$. Activation of EphA4 receptors is necessary for remodeling of CA1 dendritic spines in processes of synaptic plasticity in the adult brain [45-47], and EphA4 null mice have hippocampal distorted spines, confirming that EphA4 is required to maintain normal spine architecture in vivo $[14,48]$. An early decrease in EphA4 receptor protein was found in the hippocampus of $\mathrm{hA} \beta \mathrm{PP}_{\text {swe-ind }}$ mice, which may account for the impairment in synaptic plasticity in this brain region particularly vulnerable to degeneration in AD. Some reports have shown that inactivation of EphA receptors impairs performance of mice in behavioral tasks $[49,50]$. It is conceivable that the early decrease of EphA4 receptor levels found in mice overexpressing mutant $\mathrm{hA} \beta \mathrm{PP}$, before the onset of cognitive deficits, may affect the capacity to remodel the cytoskeleton and also the instauration of plasticity changes associated with memory in these animals. The reduction of EphA4 receptor levels was confirmed in another transgenic A $\beta$ PP line, Tg2576 mice, before the onset of cognitive decline which is not apparent in these mice until they are 9-10 month-old, at least in the water-maze test [32].

In regard to EphB2 receptor levels in the hippocampus of $\mathrm{hA} \beta \mathrm{PP}_{\text {swe-ind }}$ mice, we found an early decrease of EphB2 receptors in 2-month-old animals with no significant changes being observed at later ages (48 months). A reduction in EphB2 receptor levels was also found in $\operatorname{Tg} 2576$ mice at a single time point. It is known that EphB receptor signaling regulates synaptogenesis and dendritic spine morphogenesis and has also been implicated in the development of excitatory synapses $[19,51,52]$. The early decrease in hippocampal EphB2 levels may consequently contribute to impairing synaptic plasticity in $\mathrm{hA} \beta \mathrm{PP}_{\text {swe-ind }}$ mice.
EphB2 levels were not however reduced in 4- and 8month-old mice, but rather tended to be slightly increased. The interpretation of the latter finding is unclear and may perhaps represent an attempt to compensate for the subsequent synaptic dysfunction in $\mathrm{hA} \beta \mathrm{PP}_{\text {swe-ind }}$ mice. In line with these results, a transient increase in EphB receptor expression within two weeks of entorhinal deafferentation in mice has been reported suggesting that, in addition to its role in synaptic plasticity in normal brain, EphB receptors may be also involved in plasticity of the lesioned adult hippocampus [53].

In both $\mathrm{hA} \beta \mathrm{PP}_{\text {swe-ind }}$ and $\mathrm{Tg} 2576$ mice, there is an age-dependent cognitive decline, not only in spatial memory but also in other learning and memory tasks $[31,32,54]$. Transgenic mice do not recapitulate, however, the full phenotype of AD. Even though these mice are suitable for identification of therapeutic targets, a validation in brains from AD patients is necessary. Interestingly, a decrease in EphA4 and EphB2 receptor levels was also found in postmortem hippocampal sections from patients at a rather incipient stage of AD. This finding obviously supports the possible role of Eph receptor alterations in the pathogenesis of AD.

Among downstream effectors of Eph receptors known to modulate actin cytoskeleton [13], a key molecule is cofilin, an actin binding protein that critically controls cytoskeleton dynamics by enhancing actin depolymerization [27]. Cofilin is inactivated by phosphorylation at Ser3 so dephosphorylation of this residue leads to cofilin activation and binding to actin with the subsequent depolymerization and alterations in the regulation of synaptic plasticity. It has been reported that learning increases the number of spines containing high concentrations of phosho-cofilin, also an essential step in LTP [55]. A recent study showed that EphA4 receptor reduces the association of cofilin with the plasma membrane in heterologous cells and organotypic hippocampal slices from non-transgenic mice, suggesting a possible mechanism for the regulation of synaptic structure through an EphA4 signaling pathway [15]. In $\mathrm{hA} \beta \mathrm{PP}_{\text {swe-ind }}$ mice with a reduced EphA4 expression, we found however a small decrease of cofilin in hippocampus membrane preparations. Obviously, this result, obtained from hippocampal extracts of $\mathrm{A} \beta \mathrm{PP}$ transgenic mice, cannot be strictly compared with those of Zhou et al. [15] using heterologous cell or organotypic cultures. Our most significant finding in this part of the study was the marked decrease in phospho-cofilin(Ser3) in membrane hippocampal preparations from 4-month-old $\mathrm{hA} \beta \mathrm{PP}_{\text {swe-ind }}$ mice, 
reflecting an activation of cofilin that may cause cytoskeletal changes and altered synaptic function. Reduced phospho-cofilin levels could be a consequence of the early decrease found in the levels of phospho-PAK and phospho-LIM-kinase, key enzymes in the negative regulation of cofilin activity [38,39]. Consistent with the above findings, EphA4 receptor activation in a neuroblastoma cell line markedly increased phosphocofilin levels, although the ligand used not only activates EphA4 receptors but also the EphB receptor class [42]. Our results agree with recent studies showing that $\mathrm{A} \beta_{42}$ peptide induces dephosphorylation (activation) of cofilin and formation of rod-shaped actin bundles which may inhibit axonal transport, are sites of $\mathrm{A} \beta \mathrm{PP}$ accumulation and contribute to the pathology of $\mathrm{AD}[29,30]$. $\mathrm{A} \beta$ oligomers induce a decrease in spine density which seems to require active cofilin, so prevention of cofilin activation by expressing a mutant cofilin prevents the $\mathrm{A} \beta$-induced spine loss. Controversial findings, however, have been also reported. Heredia and colleagues [28] observed that $\mathrm{A} \beta$-induced dystrophy requires LIM-kinase-mediated phosphorylation of cofilin and, according to these authors, the difference with the studies of Maloney et al. [30] may be related to the $\mathrm{A} \beta$ dose or to the culture conditions. Furthermore, it has been reported that cofilin signaling is perturbed in $\mathrm{AD}$ brain tissue and active cofilin bound to actin was found in pathological inclusions associated to $\mathrm{AD}[30$, 56].

The critical role of excitatory neurotransmission in the induction and maintenance of processes of synaptic plasticity is well known. A dysfunction of the glutamatergic system has been found in AD [24] and, particularly, reduced surface amounts of NMDA and AMPA receptors have been reported in cultured neurons from $\mathrm{A} \beta \mathrm{PP}$ transgenic mice (see Introduction). Given the regulation of the glutamatergic system by Eph receptors [19,57-60] and the early changes found in $\mathrm{hA} \beta \mathrm{PP}_{\text {swe/ind }}$ mice, we analyzed the time-dependent modification of AMPA receptor subunits in these transgenic mice. At early times (2-4 months) of pathology progress, GluR1 and GluR2/3 levels were not altered in hippocampal membranes. At a later time (8 months of age), with histopathological abnormalities already present, GluR1 subunit levels were decreased in hippocampal membranes, a loss probably associated with impaired synaptic plasticity $[61,62]$. This decrease does not seem related to previous changes in Eph receptors because the localization of GluR2/3 subunits, which may be modulated, among other factors, by EphB2 receptors [58] was not modified. It is important to note that these $\mathrm{A} \beta \mathrm{PP}$ transgenic mice showed an early (4 months of age) recognition and spatial memory impairment without any change in membrane expression of AMPA receptors at this time point. The surface expression of NMDA receptor subunits was not at all modified, not even in 8-month-old animals.

In summary we found a decrease in EphA4 and EphB2 receptor levels before the detection of memory decline in mice overexpressing mutant $\mathrm{hA} \beta \mathrm{PP}$. These changes may account for modifications in cytoskeleton architecture, possibly associated with reduced phospho-cofilin levels, and for dynamic changes affecting the correct instauration of synaptic plasticity processes. The reported changes suggest an early synaptic dysfunction in the hippocampus that, along with other facts associated to $\mathrm{hA} \beta \mathrm{PP}$ overexpression, may lead to memory impairment in these transgenic $\mathrm{A} \beta \mathrm{PP}$ mice. The reduced EphA 4 and EphB2 receptor levels in postmortem hippocampal tissue from patients at an incipient stage of AD support the hypothesis that Eph receptors may represent a target for novel therapeutic strategies in AD.

\section{ACKNOWLEDGMENTS}

Supported by SAF2005-05086, SAF2008-02342 (Ministry of Science), CIBERNED (Ministry of Health), Government of Navarra and UTE project FIMA. We thank Dr. Lennart Mucke (Gladstone Institute, San Francisco, USA) for the transgenic $\mathrm{hA} \beta \mathrm{PP}_{\text {swe-ind }}$ mice. We also thank Government of Navarra and La Rioja for fellowships (AMS, LE).

\section{REFERENCES}

[1] Hardy J, Selkoe DJ (2002) The amyloid hypothesis of Alzheimer's disease: progress and problems on the road to therapeutics. Science 297, 353-356.

[2] Walsh DM, Selkoe DJ (2004) Deciphering the molecular basis of memory failure in Alzheimer's disease. Neuron 44, 181193.

[3] Arendt T (2001) Disturbance of neuronal plasticity is a critical pathogenetic event in Alzheimer's disease. Int J Dev Neurosci 19, 231-245.

[4] Selkoe DJ (2002) Alzheimer's disease is a synaptic failure. Science 298, 789-791.

[5] Lamprecht R, Le Doux J (2004) Structural plasticity and memory. Nat Rev Neurosci 5, 45-54.

[6] Lu W, Man H, Ju W, Trimble WS, MacDonald JF, Wang YT (2001) Activation of synaptic NMDA receptors induces membrane insertion of new AMPA receptors and LTP in cultured hippocampal neurons. Neuron 29, 243-254. 
[7] Yuste R, Bonhoeffer T (2001) Morphological changes in dendritic spines associated with long-term synaptic plasticity. Annu Rev Neurosci 24, 1071-1089.

[8] Ethell IM, Pasquale EB (2005) Molecular mechanisms of dendritic spine development and remodelling. Prog Neurobiol 75, 161-205.

[9] Martínez A, Soriano E (2005) Functions of ephrin/Eph interactions in the development of the nervous system: emphasis on the hippocampal system. Brain Res Rev 49, 211-226.

[10] Zhang J, Hughes S (2006) Role of the ephrin and Eph receptor tyrosine kinase families in angiogenesis and development of the cardiovascular system. J Pathol 208, 453-461.

[11] Gerlai R (2001) Eph receptors and neural plasticity. Nat Rev Neurosci 2, 205-209.

[12] Murai KK, Pasquale EB (2004) Eph receptors, ephrins, and synaptic function. Neuroscientist 10, 304-314.

[13] Murai KK, Pasquale EB (2003) 'Eph'ective signaling: forward, reverse and crosstalk. J Cell Sci 116, 2823-2832.

[14] Murai KK, Nguyen LN, Irie F, Yamaguchi Y, Pasquale EB (2003) Control of hippocampal dendritic spine morphology through ephrin-A3/EphA4 signaling. Nat Neurosci 6, 153-160.

[15] Zhou L, Martínez SJ, Haber M, Jones EV, Bouvier D, Doucet G, Corera AT, Fon EA, Zisch AH, Murai KK (2007) EphA4 signaling regulates phospholipase Cgamma1 activation, cofilin membrane association, and dendritic spine morphology. $J$ Neurosci 27, 5127-5138.

[16] Kayser MS, McClelland AC, Hughes EG, Dalva M.B (2006) Intracellular and trans-synaptic regulation of glutamatergic synaptogenesis by EphB receptors. J Neurosci 26, 121521264.

[17] Grunwald IC, Korte M, Wolfer D, Wilkinson GA, Unsicker K Lipp HP, Bonhoeffer T, Klein R (2001) Kinase-independent requirement of EphB2 receptors in hippocampal synaptic plasticity. Neuron 32, 1027-1040.

[18] Grunwald IC, Korte M, Adelmann G, Plueck A, Kullander K, Adams RH, Frotscher M, Bonhoeffer T, Klein R (2004) Hippocampal plasticity requires postsynaptic ephrinBs. Nat Neurosci 7, 33-40.

[19] Henderson JT, Georgiou J, Jia Z, Robertson J, Elowe S, Roder JC, Pawson (2001) The receptor tyrosine kinase EphB2 regulates NMDA-dependent synaptic function. Neuron 32, 1041 1056.

[20] Bouvier D, Corera AT, Tremblay ME, Riad M, Chagnon M, Murai KK, Pasquale EB, Fon EA, Doucet G (2008) Presynaptic and postsynaptic localization of EphA4 and EphB2 in adult mouse forebrain. $J$ Neurochem 106, 682-695.

[21] Liebl DJ, Morris CJ, Henkemeyer M, Parada LF (2003) mRNA expression of ephrins and Eph receptor tyrosine kinases in the neonatal and adult mouse central nervous system. J Neurosci Res 71, 7-22.

[22] Lesné S, Koh MT, Kotilinek L, Kayed R, Glabe CG, Yang A Gallagher M, Ashe KH (2006) A specific amyloid-beta protein assembly in the brain impairs memory. Nature 440, 352-357.

[23] Venkitaramani DV, Chin J, Netzer WJ, Gouras GK, Lesne S, Malinow R, Lombroso PJ (2007) Beta-amyloid modulation of synaptic transmission and plasticity. J Neurosci 27, 11832 11837

[24] Carter TL, Rissman RA, Mishizen-Eberz AJ, Wolfe BB, Hamilton RL, Gandy S, Armstrong DM (2004) Differential preservation of AMPA receptor subunits in the hippocampi of Alzheimer's disease patients according to Braak stage. Exp Neurol 187, 299-309.

[25] Almeida CG, Tampellini D, Takahashi RH, Greengard P, Lin MT, Snyder EM, Gouras GK (2005) Beta-amyloid accumu- lation in APP mutant neurons reduces PSD-95 and GluR1 in synapses. Neurobiol Dis 20, 187-198.

26] Snyder EM, Nong Y, Almeida CG, Paul S, Moran T, Choi EY, Nairn AC, Salter MW, Lambroso PJ, Gouras GK, Greengard P (2005) Regulation of NMDA receptor trafficking by amyloidbeta. Nat Neurosci 8, 1051-1058.

[27] Bamburg JR (1999) Proteins of the ADF/cofilin family: essential regulators of actin dynamics. Anпu Rev Cell Dev Biol 15, 185-230.

28] Heredia L, Helguera P, de Olmos S, Kedikian G, Solá Vigo F, LaFerla F, Staufenbiel M, de Olmos J, Busciglio J, Cáceres A, Lorenzo A (2006) Phosphorylation of actin-depolymerizing factor/cofilin by LIM-kinase mediates amyloid $\beta$-induce degeneration: a potential mechanism of neuronal dystrophy in Alzheimer's disease. J Neurosci 26, 6533-6542.

[29] Maloney MT, Bamburg JR (2007) Cofilin-mediated neurodegeneration in Alzheimer's disease and other amyloidopathies. Mol Neurobiol 35, 21-44.

[30] Maloney MT, Minamide LS, Kinley AW, Boyle JA, Bamburg JR (2005) Beta-secretase-cleaved amyloid precursor protein accumulates at actin inclusions induced in neurons by stress or amyloid beta: a feedforward mechanism for Alzheimer's disease. J Neurosci 25, 11313-11321.

[31] Mucke L, Masliah E, Yu GQ, Mallory M, Rockenstein EM, Tatsuno G, Hu K, Kholodenko D, Johnson-Wood K, McConlogue L (2000) High-level neuronal expression of abeta 1-42 in wild-type human amyloid protein precursor transgenic mice: synaptotoxicity without plaque formation. J Neurosci 20, 4050-4058.

[32] Hsiao K, Chapman P, Nilsen S, Eckman C, Harigaya Y, Younkin S, Yang F, Cole G (1996) Correlative memory deficits, abeta elevation, and amyloid plaques in transgenic mice. Science 274, 99-103.

[33] Braak H, Braak E (1991) Neuropathological staging of Alzheimer-related changes. Acta Neuropathol 82, 239-259.

[34] Egea J, Nissen UV, Dufour A, Sahin M, Greer P, Kullander K, Mrsic-Flogel TD, Greenberg ME, Kiehn O, Vanderhaeghen P, Klein R (2005) Regulation of EphA4 kinase activity is required for a subset of axon guidance decisions suggesting a key role for receptor clustering in Eph function. Neuron 47, 515-528.

[35] Dunah AW, Wang Y, Yasuda RP, Kameyama K, Huganir RL, Wolfe BB, Standaert DG (2000) Alterations in subunit expression, composition, and phosphorylation of striatal N-methylD-aspartate glutamate receptors in a rat 6-hydroxydopamine model of Parkinson's disease. Mol Pharmacol 57, 342-352.

[36] Ennaceur A, Delacour J (1988) A new one-trial test for neurobiological studies of memory in rats. 1: Behavioral data. Behav Brain Res 31, 47-59.

[37] Schiapparelli L, Simón A, Del Río J, Frechilla D (2006) Opposing effects of AMPA and 5-HT1A receptor blockade on passive avoidance and object recognition performance: Correlation with AMPA receptor subunit expression in rat hippocampus. Neuropharmacology 50, 897-907.

[38] Arber S, Barbayannis FA, Hanser H, Schneider C, Stanyon CA, Bernard O and Caroni P (1998) Regulation of actin dynamics through phosphorylation of cofilin by LIM-kinase. $\mathrm{Na}$ ture 393, 805-809.

[39] Carliste HJ, Kennedy MB (2005) Spine architecture and synaptic plasticity. Trends Neurosci 28, 182-186.

[40] Irie F, Yamaguchi Y (2004) EPHB receptor signaling in dendritic spine development. Front Biosci 9, 1365-1373.

[41] Yamaguchi Y, Pasquale EB (2004) Eph receptors in the adult brain. Curr Opin Neurobiol 14, 288-296. 
[42] Chen LY, Rex CS, Casale MS, Gall CM, Lynch G (2007) Changes in synaptic morphology accompany actin signaling during LTP. J Neurosci 27, 5363-5372.

[43] Aoto J and Chen L (2007) Bidirectional ephrin/Eph signaling in synaptic functions. Brain Res 1184, 72-80.

[44] Tremblay ME, Riad M, Bouvier D, Muray KK, Pasquale EB, Descarries L, Doucet G (2007) Localization of EphA4 in axon terminals and dendritic spines of adult rat hippocampus. $J$ Comp Neurol 501, 691-702.

[45] Bourgin C, Murai KK, Richter M, Pasquale EB (2007) The EphA4 receptor regulates dendritic spine remodeling by affecting beta1-integrin signaling pathways. J Cell Biol 178, 1295-1307.

[46] Fu WY, Chen Y, Sahin M, Zhao XS, Shi L, Bikoff JB, Lai KO, Yung WH, Fu AK, Greenberg ME, Ip NY (2007) Cdk5 regulates EphA4-mediated dendritic spine retraction through an ephexin1-dependent mechanism. Nat Neurosci 10, 67-76.

[47] Richter M, Murai KK, Bourgin C, Pak D, Pasquale EB (2007) The EphA4 receptor regulates neuronal morphology through SPAR-mediated inactivation of Rap GTPases. J Neurosci 27, 14205-14215.

[48] Martínez A, Otal R, Sieber BA, Ibañez C, Soriano E (2005) Disruption of ephrin-A/EphA binding alters synaptogenesis and neural connectivity in the hippocampus. Neuroscience 135, 451-461.

[49] Gerlai R, Shinsky N, Shih A, Williams P, Winer J, Armanini M, Cairns J, Winslow W, Gao W, Phillips HS (1999) Regulation of learning by EphA receptors: a protein targeting study. $J$ Neurosci 19, 9538-9549.

[50] Gerlai R, McNamara A (2000) Anesthesia induced retrograde amnesia is ameliorated by ephrinA5-IgG in mice: EphA receptor tyrosine kinases are involved in mammalian memory. Behav Brain Res 108, 133-143.

[51] Contractor A, Rogers C, Maron C, Henkemeyer M, Swanson GT, Heinemann SF (2002) Trans-synaptic Eph receptor-ephrin signaling in hippocampal mossy fiber LTP. Science 296, 18641869.

[52] Henkemeyer M, Itkis OS, Ngo M, Hickmott PW, Ethell IM (2003) Multiple EphB receptor tyrosine kinases shape den- dritic spines in the hippocampus. J Cell Biol 163, 1313-1326.

[53] Wang Y, Ying GX, Liu X, Wang WY, Dong JH, Ni ZM, Zhou CF (2005) Induction of ephrin-B1 and EphB receptors during denervation-induced plasticity in the adult mouse hippocampus. Eur J Neurosci 21, 2336-2346.

[54] Meilandt WJ, Yu GQ, Chin J, Roberson ED, Palop JJ, Wu T, Scearce-Levie K, Mucke L (2008) Enkephalin elevations contribute to neuronal and behavioral impairments in a transgenic mouse model of Alzheimer's disease. J Neurosci 28 , 5007-5017.

[55] Fedulov V, Rex CS, Simmons DA, Palmer L, Gall CM, Lynch G (2007) Evidence that long-term potentiation occurs within individual hippocampal synapses during learning. J Neurosci 27, 8031-8039.

[56] Zhao L, Ma QL, Calon F, Harris-White ME, Yang F, Lim GP, Morihara T, Ubeda OJ, Ambegaokar S, Hansen JE, Weisbart RH, Teter B, Frautschy SA, Cole GM (2006) Role of p21activated kinase pathway defects in the cognitive deficits of Alzheimer disease. Nat Neurosci 9, 234-242.

[57] Dalva MB, Takasu MA, Lin MZ, Shamah SM, Hu L, Gale NW, Greenberg ME (2000) EphB receptors interact with NMDA receptors and regulate excitatory synapse formation. Cell $\mathbf{1 0 3}$, 945-956.

[58] Hoogenraad CC, Milstein AD, Ethell IM, Henkemeyer M, Sheng M (2005) GRIP1 controls dendrite morphogenesis by regulating EphB receptor trafficking. Nat Neurosci 8, 906-915.

[59] Takasu MA, Dalva MB, Zigmond RE, Greenberg ME (2002) Modulation of NMDA receptor-dependent calcium influx and gene expression through EphB receptors. Science 295, 491495.

[60] Torres RB, Firestein L, Dong H, Staudinger J, Olson EN, Huganir RL, Bredt DS, Gale NW, Yancopoulos GD (1998) PDZ proteins bind, cluster, and synaptically colocalize with Eph receptors and their ephrin ligands. Neuron 21, 1453-1463.

[61] Malinow R, Malenka RC (2002) AMPA receptor trafficking and synaptic plasticity. Annu Rev Neurosci 25, 103-126.

[62] Reisel D, Bannerman DM, Schmitt WB, Deacon RM, Flint J, Borchardt T, Seeburg PH, Rawlins JN (2002) Spatial memory dissociations in mice lacking GluR1. Nat Neurosci 5, 868-873. 